\title{
BEYOND JUST WAGES: AN INTERCULTURAL ANALYSIS OF MATTHEW 20:1-16
}

Jean-Claude Loba-Mkole ${ }^{1}$

University of Pretoria

Pretoria

\section{ABSTRACT}

The present study offers an intercultural exegesis of Matt 20:1-16 and shows how it provides grounds for alleviating poverty and promoting justice which goes beyond just wages. This exegesis proceeds through a constructive dialogue between a contemporary culture, a church culture and an original biblical culture. After a detailed presentation of intercultural exegesis, the concept of just wages is examined in the Democratic Republic of the Congo (DRC) and its neighbour Rwanda before exploring it in a Catholic Church culture and in an original Matthean culture. Rephrased in words borrowed from G. West, 'the world in front of the text' is here represented by a contemporary target culture, while both 'the world in the text' and 'the world behind the text' rhyme with an original biblical culture; and finally a Catholic Church culture stands for 'the world around the text.' The word 'text' refers to Christian canonical scriptures.

Keywords: Intercultural biblical analysis, Gospel of Matthew, Democratic Republic of the Congo, Rwanda.

\section{INTRODUCTION}

The text of Matt 20:1-16 is commonly known as the 'parable of the workers in the vineyard,' a title found in many translations like Contemporary English Version, French Common Language, New International Version, Good News Translation, Dutch Common Language, Luther Revised, German Common Language, or New Jerusalem Bible. This tendency is corroborated by a good number of exegetes who have

1 Jean-Claude Loba-Mkole is Extraordinary Professor at the Department of New Testament Studies, University of Pretoria, South Africa. 
devoted specific studies to the text under consideration. ' 'Nouvelle Bible Segond' and 'Traduction CEcuménique de la Bible' prefer to use respectively a slightly qualified title such as 'Ouvriers de la dernière heure' (Workers of the last hour) and 'Les ouvriers de la onzième heure' (Workers of the eleventh hour). ${ }^{3}$

Through the titles of their studies the above-mentioned authors emphasise either the spatial location (vineyard) or the temporal reference (last or eleventh hour). Though the time and space are symbolically important for this parable, it is appropriate to pay more attention to the action of justice that seems to motivate this text and interpret it as a parable of 'justice beyond just wages.' Some authors have already used the concept of justice to qualify this parable4. Besides justice, several other approaches have been applied to the same text, including historical, literary, artistic, existential, socio-scientific, and many more. Some of these approaches overlap and give interesting insights from an interdisciplinary perspective.

The present study offers an intercultural exegesis of Matt 20:1-16 viewed as a 'parable of justice beyond just wages' and arguably as a right biblical paradigm for alleviating poverty, empowering the poor, and promoting justice. The underlying hypothesis of this

2 W.A. Curtis, 'The Parable of the Laborers (Matt. Xx. 1-16),' ExpTim 38 (1926-27): 6-10; W.T. Williams, 'The Parable of the Labourers in the Vineyard (Matthew xx. 1-16),' ExpTim 50 (1938-39), 526; A. Feuillet, 'Les ouvriers de la vigne et la théologie de l'alliance,' RSR 34 (1947), 303-327; Id., 'Les ouvriers envoyés à la vigne (Mt XX, 1-16),' RevThom 79 (1979), 5-24; J. Dupont, 'Les ouvriers de la vigne (Matthieu XX, 1-16),' NRT 79 (1957), 785-97; C.L. Mitton, 'Expounding the Parables: The Workers in the Vineyard (Matthew 20:1-16),' ExpTim 77 (1965-66), 307-11; D.J.M. Derret, 'Workers in the Vineyard: A Parable of Jesus,' JJS 25 (1974), 64-91; F.C. Glover, 'Workers for the Vineyard,' ExpTim 86 (1975), 310-11; O. Spies, 'Die Arbeiter im Weinberg (Mt. 20:1-15) in islamisher Überlieferung,' ZNW" 66 (1975), 279-83; M.E. Glasswell, 'Parable of the Labourers in the Vineyard (Matthew 20,1-16),' CV 19 (1976), 61-64; W. Haubeck, 'Zum Vertändnis der Parabel von den Arbeitern im Weinberg (Mt 20,1-15),' in Wort in Zeit. Neutestamentliche Studien. Festgabe für Karl Heinrich Rengstorf zum 75. Geburtstag (ed. W. Haubeck \& M. Bachmann. Leiden: Brill, 1980), 95-107; C. Dietzfelbinger, 'Das Gleichnis von den Arbeitern im Weinberg als Jesuswort,' EvTh 43 (1983), 126-137; M.L. Barré, 'The Workers in the Vineyard,' BibTod 24 (1986), 173-80; L. Schenke, 'Die Interpretation der Parabel von den "Arbeitern im Weinberg” (Mt 20,1-15) durch Mätthaus,' in Studien zum Matthäusevangelium. Festschrift für Wilhelm Pesh (ed. L. Shenke, Stuttgart: Katholisches Bibelwerk, 1988), 245-268; M. Lowe, 'A Hebraic Approach to the Parable of the Laborers in the Vineyard,' Imm 24.25 (1990), 109-17; R. Menahem, 'Epitropos/Paqid in the Parable of the Laborers in the Vineyard,' Imm 24.25 (1990), 118-131; J.M. Tevel, 'The Labourers in the Vineyard: The Exegesis of Matthew 20,1-7 in the Early Church,' VC 46 (1992), 356-380; B.R. Doyle, 'The Place of the Parable of the Labourers in the Vineyard in Matthew 20:1-16,' AusBR 42 (1994), 39-58; C.H. Pak, 'Die Arbeiter im Weinberg (Mt 20,1-16),' BibKi 52 (1997), 136-37.

3 J. Dupont, 'Les ouvriers de la onzième heure. Mt 20,1-16,' AS 56 (1974), 16-27.

4 F. Schneider, 'Von der Gerechtigkeit Gottes: Beobachtungen zum Gleichnis von den Arbeitern im Weinberg (Mt 20,1-16),' Kairos 23 (1981), 88-95; K. Lebacqz, 'Justice, Economics, and the Uncomfortable Kingdom: Reflections on Matthew 20:1-16,' in The Annual of the Society of Christian Ethics (ed. L.L. Rasmussen. Dallas: Society of Christian Ethics, 1983), 27-53; J.D. Rodriguez, 'The Parable of the Affirmative Action Employer,' Apuntes 15.5 (1988), 418-424; C. Amjad-Ali. 'Whose Justice: The Parable of the Laborers in the Vineyard,' Al-Mushir 30 (1988), 136-140. 
study is to seek whether the struggle for just wages and its implementation contribute decisively in alleviating poverty.

\section{THE CONCEPT OF INTERCULTURAL EXEGESIS}

Using some insights from R. Bauckham, ${ }^{5}$ intercultural exegesis can be defined as an attempt to understand different meanings of a biblical text while interacting with its original context, its wider literary contexts in the canon, traditional contexts (such as its interpretation in a particular theological tradition or its traditional place in a liturgy) and contemporary contexts within which the text is being currently read. This intercultural model that comprises a threefold dimension of interaction (original contexts, traditional contexts and contemporary contexts) provides an interesting theoretical framework that can be rearranged in various ways by different practitioners. Someone can emphasise an interaction of double dimension, namely the text and the reader in flesh and blood. Both the text and the reader are to be recognized, appreciated and analysed in respect with their otherness and contexts. The text and the reader are socially and culturally conditioned 'other,' i.e. 'a historical and cultural construction involving a view of the past, the present and the future.' ${ }^{\prime}$

F.F. Segovia considers himself as a reader of bicultural identity shaped by both Hispanic and U.S. cultures. He also clearly indicates the location of his intercultural criticism as 'a continued commitment to a hermeneutics of liberation in the reading and interpretation of not only biblical but also nonbiblical texts.' 7 For him, biblical and noncanonical texts are part of historical and religious tradition that the Hispanic Americans must deal with in an attempt to make their 'home,' lift their 'voice,' and display their 'face.'8 Furthermore, the Bible is considered as an 'effective weapon' and an 'ally' of some marginalised ethnic groups that are struggling to resist the multifaceted oppression from the dominant culture. Segovia has the merit of pointing out the importance of involving biblical and non-biblical texts as well as the reader in flesh and blood in the process of intercultural criticism geared at liberating the oppressed.

5 R. Bauckham, The Bible in Politics. How to read the Bible Politically (London: SPCK, 1989), 136140.

6 Segovia, F.F. 'Towards a Hermeneutics of the Diaspora: A Hermeneutic of Otherness and Engagement,' in Reading from This Place. Volume 1: Social Location and Biblical Interpretation in the United States (ed. F.F. Segovia and M.A. Tolbert. Minneapolis, 1995), 68-70.

7 F.F. Segovia, 'Towards Intercultural Criticism: A Reading Strategy from the Diaspora,' in Reading from This Place. Volume 2: Social Location and Biblical Interpretation in Global Perspective (ed. F.F. Segovia and M.A. Tolbert. Minneapolis: Fortress Press, 1995), 327.

8 F.F. Segovia, 'Towards Intercultural Criticism,' 329; J.L. González, 'Reading from My Bicultural Place: Acts 6:1-7,' in Reading from This Place. Volume 1: Social Location and Biblical Interpretation in the United States (ed. F.F. Segovia \& M.A.Tolbert. Minneapolis: Fortress Press, 1995), 139-147; V.L. Wimbush, 'Reading Texts as Reading Ourselves: A Chapter in the History of African-American Biblical Interpretation,' in Reading from This Place, 95-108. 
However, an intercultural reading that serves as a wing of liberation paradigm might become entangled in a narrow scope of a binary opposition between the oppressed and the oppressor. The power keeps shifting endlessly from one shoulder to another. Even the wittiest brain is left gasping about the true identity of the ultimate oppressor and oppressed. Each current oppressor is more likely a former or a future oppressed and vice-versa. This is a point well taken in the interest of the present intercultural exegesis and mediation, which obviously does not limit itself strictly to biblical intertextualities as practiced by some authors9. Intercultural exegesis as more inclusive interpretive enterprise gets further support from M. Dauphinais and M. Levering who state that,

[b]iblical exegesis depends upon the exegete's gifts as a speculative theologian, which in turn depends upon the exegete's acquaintance with not merely the particular text at hand but indeed the whole Scriptures as illumined in faith by the Fathers and interpreted doctrinally by the Church. ${ }^{10}$

This statement seems to be relevant to intercultural exegesis or mediation, as long as the concept of Church includes different Christian faith traditions. As A. Yarbro-Collins has already put it, '[b]iblical theologians are not only mediators between genres. They are mediators between historical periods. ${ }^{11}$ In other words, they are mediators between different cultures; or in simpler terms they are intercultural mediators but also Christlike community builders, especially when a New Testament text is concerned.

Interculturality implies multiculturality or a plurality of cultures. Interculturality involves more interaction and constructive dialogue between cultures while multiculturality simply underscores the Dasein (the being there) of many cultures with no particular interest in building up a community of active solidarity. It is worthwhile to distinguish between vertical interculturality and horizontal interculturality. Vertical interculturality applies to the interplay between cultures that supersede and illuminate each other in a given time frame (e.g. past cultures, present cultures and future cultures). This category can include for instance biblical original cultures, particular Church cultures and contemporary target cultures. The relation between the three cultures is usually explored for a better understanding of the target cultures in the light of past events, dreams about the future and current opportunities or challenges. Horizontal interculturality, deals with the relationship between a contemporary target culture and its neighbours.

A lack of Scripture-based dialogue between the neighbouring cultures may end up creating more suspicions and misunderstandings that may fuel enmities. According to

9 S. Draisma, S., ed., Intertextuality in Biblical Writings. Festschrift B. Van Iersel (Kampen: Kok Press, 1989); D. Marguerat and A. Curtis, eds., Intertextualités: La Bible en échos (Genève: Labor et Fides, 2000); M.E. Kiessel, 'Intertextualité et hypertextualité en Jn 11,1-12,11,' ETL 81.1 (2005), 25-56.

10 M. Dauphinais and M. Levering, Reading John with St. Thomas Aquinas. Theological Exegesis and Speculative Theology (Washington: Catholic University of America, 2005), iii.

11 A. Yarbro-Collins, 'Narrative, History and Gospel,' Semeia 43 (1988), 145-153; R.E. Brown and F.J. Molonely, An Introduction to the Gospel of John (New York: Doubleday, 2003), 36. 
G.I. Akper, South African theologians such as Masenya and Snyman do not see black and white cultures interacting with each other to produce a 'family' of theologies and people of (South) Africa while West and Tutu represent an interculturality school of theology, encouraging an interface between people with different cultures to relate to each other. ${ }^{12}$ In the view of K.I. August, multiculturality often emphasizes the heterogeneity of different ethnic groups in society whereas intercultural highlights relationality beyond relativism. ${ }^{13} \mathrm{~L}$. Jonker goes as far as to state:

In a glocal (global-local) world intercultural exchange seems inevitable. The world has become a multicultural society within which globalization makes intercultural exchange inevitable. ${ }^{14}$

Regarding the intercultural biblical hermeneutics, he underscores the importance of basic conditions laid down by Kool and De Wit, which include an attitude of openness, knowledge of how cultures operate and insight into the group's own reading. ${ }^{15}$ Here, culture is not defined in static terms of a holistic system that gives meaning to the world. Culture is rather a system in constant movement and a permanent process of meaning construction. Three features characterise this culture: it is ideational as it provides frameworks of meaning for interpreting the world; it is performanative, as it includes rituals; and it is material, as it produces artefacts and symbols (language, food, clothes, music, organization of space, etc.). ${ }^{16}$

A fuller account of intercultural exegesis combines both vertical and horizontal interculturalities. A given subject of an intercultural exegesis is then analysed against the views of the cultures involved, ${ }^{17}$ whether they are accommodating or confrontational experiences between targeted and neighbouring cultures (horizontal interculturality), as well as in the light of the past and future cultures (vertical interculturality). The focus however is placed on the target culture, being the entity that has undertaken the process of interacting with other cultures in order to reach a fuller understanding and improvement of its own identity and live in a better relationship with itself and its neighbours.

The present intercultural exegesis will start by examining the concept of just wages in the DRC and its neighbour Rwanda before exploring it in a Catholic Church culture and in an original Matthean culture. Rephrased in words borrowed from G. West, 'the world in front of the text' is here represented by a contemporary target culture, while

12 G.I. Akper, 'From Multiculturality to Interculturality? Locating the Ongoing African Agency Discourse in the Debate,' Scriptura 91.1 (2006), 6.

13 K.T. August, 'The Nature of Interculturality in Development: A Theological Perspective of Relationality,' Scriptura 91.1 (2006), 15.

14 L. Jonker, 'From Multiculturality to Interculturality: Can Intercultural Biblical Hermeneutics Be of Any Assistance?’ Scriptura 91.1 (2006), 22.

15 Ibid., 27.

16 Ibid., 21.

17 See J.C. Loba-Mkole, 'The New Testament and Intercultural Exegesis in Africa,' JSNT 30.1 (2007), $7-28$. 
both 'the world in the text' and 'the world behind the text' rhyme with an original biblical culture; and finally a Catholic Church culture stands for 'the world around the text.' ${ }^{18}$ The word 'text' refers to Christian canonical scriptures.

\section{JUST WAGES IN CONTEMPORARY AFRICAN CULTURES (THE WORLD IN FRONT OF THE TEXT)}

\subsection{TARGET CULTURE: THE DRC}

The deadliest disease in Africa in general and in the DRC in particular may be neither HIV/AIDS nor Tuberculosis nor Malaria nor corruption nor war but poverty in terms of international standards. According to the 2004 survey by the World Bank, except for the Republic of South Africa and the Maghreb countries, the majority of African countries live in poverty, though with some distinction between moderate, extreme or non-classified poverty. Moderate poverty includes the countries where more than $25 \%$ of the population live below U\$ 2 per day. In the case of extreme poverty, more than $25 \%$ of the population live below U\$ 1 per day. The category of non-classified poverty applies to countries where the data needed was not available. The DRC may belong to this category. Indeed, since the second half of the 1970's the standard of living in the DRC started declining and has not improved even after the end of Mobutu's era in 1997, though he was categorised as 'l'incarnation du mal zairois' (incarnation of Zairean evil). The standard of living worsened after his departure even if some hope was recently raised following the relatively peaceful general elections of 2006 and 2011. An Index Mundi comparison shows that out of 226 countries worldwide, the DRC is placed last with a per capita GDP of U\$ 400, while the neighbouring Rwanda occupies the $202^{\text {nd }}$ position with a per capita GDP of \$ 1400 .

Talking about 'right wages' in the DRC is a daydream, as long as the state of affairs in this country reflects what the African Synod of 1994 described as nasty misery, bad governance, political instability, and social disorientation, which instils the idea of anthropological poverty and afro-pessimism. ${ }^{19}$ This sense of disorientation can be collaborated by a survey which shows that the majority of the Congolese interviewed do not know the basics that could allow them to overcome this long lasting crisis, namely fundamental factors such as work, science, technology, ethics, education and the culture of performance:

18 G. West, Biblical Hermeneutics of Liberation. Modes of Readings the Bible in the South African Context (Pietermaritzburg: Cluster; New York: Orbis Books, 1995).

19 Jean-Paul II, Exhortation apostolique post-synodale Ecclesia in Africa (Kinshasa: Mediapaul, 1995); E.B. Ung'eyowun, 'Les défis de l'évangélisation et de l'engagement missionnaire renouvelé en Afrique,' Revue Africaine des Sciences de la Mission 20/21 (2005), 185-196; L. Santedi, 'Les défis de l'évangélisation dans l'Afrique contemporaine,' Inculturation de la vie consacrée en Afrique à l'aube du troisième millénaire (ed. J. Kalonga, Kinshasa: Carmel Afrique, 1998), 187-199. 
Ces exigences fondamentales du développement échappent à la conscience collective des Congolais enquêtés! Et ce sont des licenciés et gradués: 1246 sur 1804. Ils ignorant donc ce qu'il faut faire absolument pour développer le Congo! ${ }^{20}$ (These basic requirements for development escape to the collective awareness of the Congolese interviewed! And they have Masters and Bachelor degrees: 1246 out of 1804. They then ignore what should be done to develop Congo!)

Only an average frequency of $17,9 \%$ of people interviewed have mentioned some of the basic factors conducive for the development: work (32,7\%), science $(28,2 \%)$, ethics $(24,1 \%)$, education $(15 \%)$, technology $(6,9 \%)$, and a culture of performance $(0 \%)$. The majority $(82,1 \%)$ gave answers that the surveyor deemed irrelevant, which included things like good governance, democracy, good salaries, etc. It is interesting to note that the reviewer considers good governance, democracy, and good salaries as irrelevant answers. He did not elaborate on this assessment. One might support his stand because all these three factors presuppose the basic ones such as work, science and ethics. If one groups science, education and technology together the value allocated to learning, one would score $50.1 \%$. The learning system would thus be the most important sector to promote, followed by work and ethics. In fact, countries that aim at development keep investing constantly in research, job creation, and basic ethical values such as courage, justice, prudence, temperance, and solidarity.

At the moment the majority of the Congolese middle class is underpaid, a situation that weakens both the private and public sectors. Yet, the country has an immense potential wealth in terms of natural and human resources. In view of the historian I. Ndaywel è Nziem, the Congolese economic take-off can be envisaged as a realist project in short and long terms where the revision of national economic structure is indispensable for moving forward in a spirit of equitable sharing that will allow all to build an acceptable living standard, far from the spectrum of misery and famine. ${ }^{21}$ There is hope for a bright future for the DRC and for Africa in general. Some countries with fewer resources are thriving and have turned a new leaf in terms of economic growth. Rwanda, a neighbouring country to the DRC is one case in point.

\subsection{NEIGHBOURING CULTURE: RWANDA}

The DRC is surrounded by 9 neighbouring countries: Angola and Congo-Brazzaville in the West; Zambia in the South; Tanzania, Uganda, Burundi, and Rwanda in the East; and lastly the Central African Republic and South Sudan in the North. None of the neighbouring countries have been involved in intense and sometimes conflicting transactions with the DRC more than Rwanda. For the sake of their respective citizens and for the development of the Great Lake region of Africa, the DRC and Rwanda

20 C. Izia-Mpey, 'Education congolaise et exigences fondamentales du développement,' Revue Africaine des Sciences de la Mission 20/21 (2005), 203.

21 I. Ndaywel è Nziem, Histoire générale du Congo. De l'héritage ancien a la République Démocratique (Paris-Bruxelles: Duculot, 1998), 817. 
have a lot to gain in building up good relations. Such a move entails that each of the two countries come to understand its own identity not only from its own perspective, but also from that of its neighbour. In fact, the diplomatic relations between the two countries still suffer from prejudices formed during the deadly Congolese war which began in 1998 and officially ended in 2002, but which is still continuing up to today with Rwandan involvement. It is not an easy task to tell which ruler is a rebel or not, since many in Africa seize power through armed rebellions or rigged elections. That is not the point here, however; what is more regrettable is that some Congolese and Rwandese are developing mutual hatred that is translated into insult, disdain, humiliation, and killing. Despite this sad state of affairs the DRC and Rwanda are still neighbours and cannot afford to ignore or hurt each other. This is the context in which I invite the DRC to seek solutions to its problems with its neighbour, the Rwandan Republic - through dialogue. Some structural initiatives already exist for deepening the understanding not only between the two countries, but also with some neighbours they have in common like Burundi, Tanzania, and Uganda. With Burundi, they share membership of ACEAC (Association de Conférences Episcopales de l'Afrique Centrale) while all three are joined by Kenya, Uganda, and Tanzania in CPGL (Communauté des Pays des Grands Lacs). On a more global scene, both Rwanda and the DRC receive donations from the same international bodies. In one way or another, Rwandese and Congolese cows basically drink from the same streams. Do they need to fight? Do they need international mediators and peacekeepers? Do they need to run away from one another? For how long and how far? Can they not think for themselves and sort out their brotherly disagreements?

More than a decade after the Rwandese tragedy of 1994 and even before this, the Rwandese job market has attracted Congolese citizens with its more comfortable wages and better communication infrastructure. It is also important to keep in mind that before the 1994 tragedy and even thereafter, some Rwandese got lucrative deals in the DRC, especially in political and socio-economic sectors. However, sometimes it becomes hard to distinguish which Rwandese is Rwandese and which one is Congolese. Some of them navigate between Congolese and Rwandese nationalities, although the DRC does not officially allow dual citizenship. But, the African Union to which both countries belong should push for African citizenship to promote African brotherhood.

In recent times the standard of living has improved in Rwanda with regard to hygiene, order, discipline and comfort in the public sector also in terms of attracting wages. There might still be room for improvement especially in the area of the relationship between Tutsis and the Hutus in Rwanda and beyond, perhaps by integrating both ethnic groups in the process of reconstructing the country. The present Rwandan government can be proud of the steps achieved so far in terms of material development, including the policy of de-ethnicization of Rwandese citizens. Even if a minority in power is spearheading this development, the standard set for the employees in terms of competitive wages, as well as with regard to discipline in the public sector is commendable. In view of these 
two factors (competitive wages and discipline in the public sector), some Rwandese citizens do not hesitate to resign from highly paid jobs in the U.S. and Europe and come back home. There are, however, other Rwandese outside their country, still fearing the consequences of Tutsi-Hutu conflicts, though the current government claims to accommodate all Rwandese without any ethnic bias. Nevertheless, Church leaders can contribute significantly to avoid the repetition of some of the errors and contradictions of which some Catholics have been accused:

Pendant des nombreuses années, l'Eglise a fait alliance avec la monarchie et soutenue l'ethnie tutsi dans les privileges dont elle jouissait, puis peu d'années avant l'indépendance, elle soutint la majorité hutu, dans ses révendications démocratiques (During many years, the Church had made a covenant with the ruling monarchy and supported the Tutsi ethnic group in the privileges they were enjoying, then few years before the independence, the Church supported the majority Hutu ethnic group in their claim for democracy.) $)^{22}$

If the Tutsi-Hutu conflict is considered as a challenge that needs to be properly addressed in a sustainable process of healing the Rwandan society, the latter can nevertheless inspire the Congolese nation in the way it is tackling developmental issues. Rwandese political leaders and civil societies seem to be capable of understanding and carrying out their responsibility towards the betterment of their national destiny. It is amazing to see how the present regime endeavours to foster development patterns in the post-war Rwanda. When a tourist visits Rwanda, s/he cannot fail to notice tangible signs of development and the presence of a government in charge, which is visible through adequate public communication infrastructure and discipline. In doing so, the Rwandan government honours its citizens and tourists by maintaining a healthy environment, which is a significant incentive for the labourers beside their regular wages. Nonetheless, as Rwandese are still nursing the wounds of the 1994 massacre, fratricide or genocide, the current focus on environmental beauty and human development may need to go hand in hand with the conversion of heart and civilisation of love, which is stronger than hatred and death. ${ }^{23}$

A striking cultural difference between the DRC and Rwanda is the fact that managers of the former imagine that their citizens can work without regular and just wages while the latter strives to progress in the opposite direction. In fact, in cultural terms, Congolese ideational and performance frameworks are negatively affected by the failure in improving material culture in terms of effective organization of space and people. These are areas where the Rwandese current government is making a commendable progress, though there is still, room for improvement. Congolese territory and people are there but not adequately managed, organised, coordinated nor disciplined. As a

22 J. Kalibwana, Le Catholicisme et la societé rwandaise 1900-1962 (Paris : Présence Africaine, 1991), 14; P. Rutayisire, La Christianisation du Rwanda (1900-1945). Méthode missionnaire et politique selon Mgr Léon Classe (Fribourg: Editions Universitaires, 1987), 27, 135; I. Linden, Christianisme et pouvoirs au Rwanda (1900-1990) (Paris: Karthala, 1999), 201, 401.

23 K. Bahujimihigo, Témoins de Dieu dans un pays meurtri (Kigali: Pallotti Press, 1998), 35-36. 
result, even a basic concept such as the just wage is out of reach in many vital sectors of life and the consequences are disastrous. How is this issue of just wages addressed in a Church tradition culture, namely that of a Catholic Church?

\section{JUST WAGE IN A CATHOLIC CHURCH CULTURE (THE WORLD AROUND THE TEXT)}

Catholic teaching about just wage is well summarised in the Compendium of the Social Doctrine of the Church. ${ }^{24}$ According to this document, the rights of workers, like all other rights, are based on the nature of the human person and on his transcendent dignity. These rights are often infringed when workers are underpaid or subjected to inhumane conditions without protection or adequate representation. ${ }^{25}$ Remuneration remains the most important means for achieving justice in a work relationship while the just wage is qualified as the legitimate fruit of work. Accordingly, 'they commit grave injustice who refuse to pay a just wage or who do not give it in due time and in proportion to the work done (cf. Lev 19:13; Deut 24:14-15; Jas 5:4). ${ }^{26}$ A just wage is understood as means which can allow the labourer 'to cultivate worthily his own material, social, cultural, and spiritual life and that of his dependants, in view of the function and productiveness of each one, the conditions of the factory or workshop, and the common good. ${ }^{27}$ Furthermore, the compendium notes that the contract between the employer and the employee is not sufficient for the agreed-upon salary to qualify as a 'just wage', because a just wage 'must not be below the level of subsistence' of the worker (i.e. natural justice or common sense is above the freedom of contract). ${ }^{28}$ P.C. De Lichtbuer argues that Matt 20:1-16 is about the right for all the workers to receive the reward, but not a just wage which would correspond to the work done (which is a human calculation). ${ }^{29}$ However, given that this parable teaches about justice in the reign of God, earthly ways of discharging justice needs to be taken into consideration since God's reign includes both heavenly and earthly dimensions.

In an African context, S. Muyebe and A. Muyebe have linked the most important human rights teachings from United Nations and other secular authorities with the

24 Pontifical Council for Justice and Peace, Compendium of the Social Doctrine of the Church (Vatican: Libreria Editrice Vaticana, 2004), 173-174.

25 Pontifical Council for Justice and Peace, Compendium of the Social Doctrine of the Church, 173; Leo XIII, 'Rerum Novarum,' Acta Leonis 11 (1892), 135; Pius XI, 'Quadragessimo Anno,' AAS 23 (1931), 186; Pius XII, 'Sertum Laetitiae,' AAS 31 (1939), 643; John XXIII, 'Pacem in Terris,' AAS 55 (1963), 262-263; Second Vatican Ecumenical Council, 'Gaudium et Spes,' AAS 58 (1966), 10891090; John Paul II, 'Laborem Exercens,' AAS 73 (1981), 629-632; John Paul II, 'Centesimus Annus,' AAS 83 (1991), 801-802.

26 Pontifical Council for Justice and Peace, Compendium of the Social Doctrine of the Church, 173.

27 Ibid., 174.

28 Ibid., 174.

29 P.C. De Lichtbuer, Parabels van het Koninkrijk. Jezus openbaart het gelaat van de Vader (2 vols.; Heverlee: Pierre Cardon de Lichtbuer, 2001), 214, 224. 
teachings presented in documents of Catholic bishops in Africa. Quoting the Universal Declaration of Human Rights on the right to work and employment (Art. 23), they state that the right to work and the freedom from unemployment imposes an obligation to the state to design a policy that promotes 'full, productive and freely chosen employment. ${ }^{30}$ In addition, the right to work includes the enjoyment of just and favourable working conditions such as the right to equal remuneration for work of equal value, just and fair remuneration, promotion, freedom from discrimination in the work place, a safe and healthy working environment, reasonable working hours and periodic holidays with pay. With regards to the right of wage, Muyebe and Muyebe state that this right obliges the employers to establish a just and fair remuneration in the light of a minimum wage fixed by the local government. In determining such a minimum wage, they argue, the cost of living, the needs of the workers and their families and the availability of provisions for social security should be considered. What can we learn from the original biblical culture imbedded in Matt 20:1-16?

\section{JUST WAGES IN MATT 20:1-16 (ORIGINAL BIBLICAL CULTURE)}

\subsection{SOME INTERPRETATIONS}

According to B.B. Scott, ${ }^{31}$ a standard interpretation of the parable of Matt 20:1-16 has emerged since A. Jülicher, who viewed Matt 20:1-16 as a story about a just and generous employer. ${ }^{32}$ One may recall that such interpretation goes back to the period of the Church Fathers who identified the householder with God/Christ at work for creating a new order of justice. For Cyril of Alexandria, the Lord justly gives to all their single denarius, which is the grace of the Spirit perfecting the saints in conformity with God and leading them to life and immortality. The justice of God displays its surprising power when the last labourers receive not the troubles but the generosity of the Master who treats them equally with the first-comers. ${ }^{33}$ As for John Chrysostom, the point of this parable lies in 20:14 ('I choose to give to these last as I give to you'), which underscores the free will

30 S. Muyebe and A.Muyebe, The African Bishops on Human Rights. A Resource Book (Nairobi: Paulines Publications Africa, 2001. Repr. 2002), 169.

31 B.B. Scott, Hear Then the Parable. A Commentary on the Parables of Jesus (Minneapolis: Fortress Press, 1989), 282.

32 A. Jülicher, Die Gleichnisreden Jesu (Tübingen: Mohr, 1910. Repr., 1919), 459-471. See also W. Michaelis, Die Gleichnisse Jesu (Hamburg : Furche-Verlag, 1956), 171-178; J. Dupont, 'Les Ouvriers de la vigne,' AS 22 (1965), 28-51; E. Linnemann, Jesus of the Parables (New York: Harper \& Row, 1966), 81-88; G. Ru, 'Conception of Reward in the Teaching of Jesus,' NT 8 (1966), 202-222; D. Via, Jr. The Parables. Their Literary and Existential Dimension (Philadelphia: Fortress Press, 1967), 147-155; J. Jeremias, The Parables of Jesus (New York: Charles Scriber’s Sons, 1972), 136-139.

33 Cyril of Alexandria, 'Fragmenta in Matthaeum,' in Matthäus-Kommentare aus der griechischen Kirche (ed. J. Reuss; Berlin: Akademie-Verlag, 1957), 226, 229. 
of God in the dispensation of his justice. ${ }^{34}$ No wonder that Gregory the Great can state that we must all rejoice exceedingly to be even the last in the kingdom of God. ${ }^{35}$

According to the standard interpretation, the historicity of this parable is to be located in the context in Jesus' debate with the scribes and Pharisees; it accounts for Jesus' association with the outcast and represents the free gift of God's grace. Scott is not comfortable with this standard interpretation, because: a) 'the Pharisees would not have recognized themselves in the allegorical characterisation;' b) the parable does not support the doctrine of salvation by grace alone because it does not mention a single labourer who was given the wage without working. Moreover, the so-called generosity of the employer is questionable, as a denarius represents nothing more than the average of a peasant's daily wage. Following his literary and redactional analysis, Scott argues that Matthew reads this parable as 'an example of the theme that the first shall be the last and of the moral contrast between good and evil. Besides, he identifies the householder with Jesus and considers as authentic not only v. 16 but also vv. 14b-15 and eventually v.8c. ${ }^{36}$ Scott explains that the first who will be the last are the Pharisees, those who have tested the Lord and failed in the divorce question (19:3-9), and those last who will be first are the disciples, who are promised to sit on the thrones of Israel for having left everything and followed Jesus (19:27-30). ${ }^{37}$ Furthermore, he points out that the crux of interpretation is the accusation of injustice about the payment to the first labourers. The parable relativizes justice to show how the latter is incapable of organising the world of the kingdom. For the parable, value or worth (i.e. a place in the kingdom) is determined not by what is right but by acceptance:

Those commentators who have seen in the parable a justification for Jesus' association with the outcast are correct, insofar as the parable provokes a response in which all are invited to the kingdom not on just deserts but by invitation. ${ }^{38}$

Nonetheless, this invitation is honoured by both acceptance (agreement) and actual work in the vineyard. More interestingly, Luz combines both the text's influence or 'effective history' (Wirkungsgeschicthe) and the history of interpretation (Auslegunsgechicthe). Earlier on he understood effective history of the biblical texts as synonymous with their reception history, ${ }^{39}$ but some years later he dissociated himself from the history of reception (Rezeptionsgechichte), since for him the latter 'connotes primarily the

34 John Chrysostom, 'Homiliae in Matthaeum 64.3,' in PG 58 (ed. J.P. Migne; Paris: Brepols, 1862), 613.

35 Gregory the Great, 'XL Homiliarum in Evangelica,' in PL 76 (ed. J.P. Migne; Paris: Brepols, 1857), 1156-1157; Cyril of Alexandria, 'Fragmenta in Matthaeum,' 226, 229; Gregory the Great, 'XL Homiliarum in Evangelica,' 613; M. Simonetti, Ancient Christian Commentary on Scripture. New Testament.. Matthew 14-28 (Downers Grove: InterVarsity Press, 2001), 106-112.

36 B.B. Scott, Hear Then the Parable, 287.

37 Ibid., 285.

38 Ibid., 297.

39 U. Luz, Studies in Matthew (Grand Rapids: Eerdmans, 2005), 351. 
people who receive the text' and not the effect of the text. ${ }^{40}$ Nonetheless, in the history of interpretation Luz revisits some faith communities such Reformation, Protestant Liberal, Catholic, Ancient Church, and Jewish interpretations. He points out that the major Western confessions agree with Jeremias ${ }^{41}$ for whom this parable unveils two worlds: 'the world of merit, and the world of grace; the law is contrasted with the gospel.' For Luz, Reformation with its antithesis of 'works people' and 'faith people,' meant a new beginning for the interpretation of Matt 20:1-16. Workers hired earlier are identified with works people who demand to be paid for their accomplishments while those hired later are regarded as persons of faith who had no claims before God, but receive the same reward..$^{42} \mathrm{He}$ favours the Protestant interpretation against the Protestant liberal interpretation based on Kantian 'idealistic ethic of duty,' the traditional Catholic doctrine of reward, and the early Christian allegorical interpretation that features the stages of salvation-history (for instance, Irenaeus and Origen) or Jewish meritocracy.

\subsection{LITERARY ANALYSIS OF MATT 20:1-16 (THE WORLD IN THE TEXT)}

With thephrase $\square \mu \mathrm{o} \square \alpha \gamma \square \rho \square \sigma \tau \mathrm{v} \square \beta \alpha \sigma \mathrm{c} \lambda \varepsilon \square \alpha \tau \square$ vo $\square \rho \alpha v \square v$ (Matt20:1)presentsaclassic terminus a quo (starting point or point of departure) of introducing a parable narrative in the synoptic gospels (cf. Matt 13:24, 31, 33, 44, 45, 47; 18:23; 22:2; 25:1; Mark 4:26; Lk 13:18). The conjunction $\gamma \square \rho$ connects the present text with the preceding section to provide a further explanation about the pronouncement of Matt 19:30 (but many that are first will be last and the last first). This very statement is rephrased at the end of the parable in 20:16 (so the last will be first and the first last), and constitutes the terminus ad quem (final point or point of arrival). The boundaries of Matt 20:1-16 are therefore clearly marked by the statement about the first being the last and vice-versa. This logic is proclaimed in Matt 19:30 about inheriting the eternal life; this is further explained through a parable about the reign of heaven (Matt 20:1-15), of which the concluding remark (Matt 20:16) reinforces the whole argumentation. It is important to note that eternal life (Matt 19:16-30) and reign of heaven (20:1-16) are synonymous expressions and both operates within the logic of last being the first and vice-versa. However, some manuscripts (C D W 038 f 13 33. 700 Majority text latt sy mae bopt Or) provide an additional explanation for this logic, 'for many will be called but few chosen.' J.M. Lagrange argues that the omission of this reading is typically Egyptian (cf. $01 \mathrm{~B} \mathrm{~L} \mathrm{Z}$ 085. 892* 1424. 1844 pc sa bopt), but he still prefers the shorter reading, given that the longer one might have been taken from 22:14. ${ }^{43}$ Strictly, each of the two readings betrays a redactional activity willing to make it clearer to Jewish Christians that the

40 U. Luz, Matthew 1-7 (Minneapolis: Fortress Press, 2007), 61; H. Räisänen. Challenge to Biblical Interpretation, Essays 1991-2000(Leiden: Bril, 2001), 269; A.C. Thiselton, Thiselton on Hermeneutics. Collected Works and New Essays of Anthony C. Thiselton (Aldershot: Ashgate, 2006), 42.

41 J. Jeremias, The Parables of Jesus, 139.

42 U. Luz, Matthew 8-20 (Minneapolis: Fortress Press, 2001), 528.

43 M.J. Lagrange, L'Evangile selon Saint Matthieu (Paris: Gabalda, 1941), 390. 
favours of God's reign are distributed equally to both Jews and Gentiles who accept the invitation to cooperate with the divine plan.

This lesson is implicitly unmistakable from the body of the parable even if it was not explicitly recorded. In a 'high-context society' like the first century Mediterranean world, implicit messages are more communicative than the explicit ones. As Lagrange put it, the conclusion in v. 16 was added 'contre ceux qui sont assez aveugles pour ne pas y adherer' (against those who are so blind not to adhere to it). The section that follows Matt 20:16 deals with a different topic pertaining to the prediction of the death and resurrection of the Son of man (20:17-19). E. Drewermann, ${ }^{44}$ however, views the whole section of Matt 20:1-19 as a unit. In this delimitation, he concedes that Matt 20:1-16 represents the foundation of the coming drama that Jesus predicts for the third time here in 20:17-19 after 16:21-23 and 17:22-23. This drama that was in a certain way alluded to in Matt 10:28 (not fear what kills your body...) had evolved to concentrate itself on the paschal mystery of Jesus for the sake of justice. The latter is interested much more in 'was Menschen brauchen, wessen sie beduerfen, was sie noetig haben, um zu existieren' (what people want, what is necessary, what they need for living). ${ }^{45}$ The landlord in the parable follows this logic when rewarding his workers. Though Drewermann demonstrates how to understand the justice performed in this parable in the light of the coming paschal mystery, the vineyard labourers' story ends with the redactional and concluding remarks of v. 16, as v. 17 begins a relatively new narrative which depicts Jesus and his disciples on their way to Jerusalem.

The internal coherence of Matt 20:1-16 evolves around the characters of the story (householder and labourers), the spatial location (vineyard) and the timeframe (morning $1^{\text {st }}$ hour, $3^{\text {rd }}$ hour, $6^{\text {th }}$ hour, afternoon $9^{\text {th }}$ hour, $11^{\text {th }}$ hour and evening). The householder or the landlord is the second term of the simile in which the reign of God that represents the first term finds a vivid analogy. This householder becomes the leading figure of the story: he is on the move from the very beginning (20:1) until the end of the narrative (20:15-16). The narrative flow is built up around his undertakings, which are well timed. In the morning he goes out to hire labours for his vineyard and agrees with them about the wage of one denarius (20:1-2). He resumes the recruitment at each critical hour of the day (3-7). When the evening comes he honours his word, pays what he had promised, which he qualifies as right because he is good (8-16).

The last section is full of surprises. Firstly, the landlord uses a foreman to pay the labourers on his behalf, something he did not do when he was hiring them (8). Secondly, he instructs the business manager to start the wage remittance with the last-comers or the labourers of the $11^{\text {th }}$ hour to whom he gives one denarius, which was the equivalent of a whole day's work (9). Thirdly, the first-comers are given the same amount as that received by the last-comers (10). Fourthly, the last-comers address their protest not to the foreman who has paid them but directly to the landlord (11-12). As a matter of fact,

44 E. Drewermann, Das Matthausevangelium. Bilder der Erfuellung (Düsseldorf: Walter, 1994), 500.

45 Ibid., 503. 


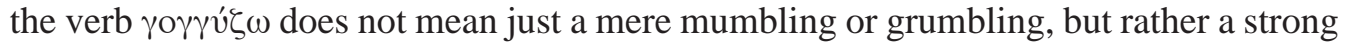
and violent protest (cf. Exod 15:24; 16:2; Num 14; 36). ${ }^{46}$ Amazingly, the major reproach that the protestors are making to the landlord is the fact that they are given the same reward as the last-comers (12). Fifthly, the business manager keeps quiet and does not express any support toward the boss or the labourers. Either he is not aware of what is at stake or he knows that both sides are partly right and partly wrong, but he cannot say it. Sixthly, the landlord responds to the outcry by talking only to one of the protesters whom he even calls friend (13-15). Seventhly, the landlord's self-defence that is built on rhetorical questions focuses on his non-wrong doing motives that are equated with justice. He respects the agreement that he had made with the first hour labourers who have become the protesters (13), he is free - he is not bound by any agreement to extend to the last-comers what he did to the first ones with contract (14). He allows himself to do whatever he wants with his wealth (14), others (i.e. first hour labourers) might be jealous (literally their eyes are bad) because he is good (15). Here the landlord hit the biggest weakness of his opponents: their protest was mainly based on jealousy (cf. 12, 15). The landlord's argument seems to be final. He does not tolerate anyone to question his standard of justice when he gives one denarius to all the labourers regardless their different toil and irrespective of agreement or non-agreement. This is much more surprising and echoes some injustice.

The redactor himself does not insist on this subtle unfairness, as he makes no comment on this issue but rather provides a concluding and final remark from his perspective: 'So the last will be first, and the first will be last' (16). In so doing, he sides with the landlord in honouring the last-comers who deserved a lesser reward than the grumbling and jealous first-comers. This parable teaches another level of justice, namely that which consists of granting to someone more than what he or she deserves, caring for the labourer beyond just wage calculations.

The internal coherence of this parable seems to evolve around the notion of justice, as displayed by the landlord or as captured by Matthew.

\subsection{HISTORICAL BACKGROUND OF MATT 20:1-16 (THE WORLD BEHIND THE TEXT)}

Being a parable the text of Matt 20:1-16 is not a photographic description of a historical event. The parable has been told as a realistic fiction to address some socio-economic injustices.$^{47}$ It is important to find out how it would make sense in the ears of its first historical audiences. For B. Malina and L. Rohrbaugh, the picture described in Matt

46 F.X. De Guibert, Evangile de Matthieu (Paris: De Guibert, 1996), 419.

47 See E.K. Vearncombe, 'Redistribution and Reciprocity: A Socio-Economic Interpretation of the Parable of the Labourers in the Vineyard (Matthew 20.1-15),' JSHJ 8 (2010), 199-236; J.S. Kloppenborg, 'The Growth and Impact of Agricultural Tenancy in Jewish Palestine (III bce-I ce),' JESHO 51.1 (2008), 31-66; Id., The Tenants in the Vineyard: Ideology, Economics, and Agrarian Conflict in Jewish Palestine (WUNT 195; Tübingen: Mohr-Siebeck, 2006). 
20:1-16 can be easily placed in the experience of Mediterranean peasants. In this context, day labourers, as it is the case in this parable, were known to be among the economically poorest people in the society. ${ }^{48}$ As a matter of fact, 'they were landless peasants who had lost their ancestral lands through debt and drifted into cities and villages looking for work. ${ }^{49}$ Furthermore, 'the fact that it is harvest time in the story makes it more likely that those described here are not those with land of their own or they would be at home working. ${ }^{50}$

In Palestine during the time of Jesus, patrons were high-status, well-situated, and powerful individuals who controlled the first order resources such as land, jobs, goods, funds, and power. To honour their status, they were expected to grant generously some favours to their clients. In the text of Matt 20:1-20, the patron shows his patronage and generosity by giving to the last hour workers as much wage as that which was given to the first-comers (v. 14). If this was the case, the generosity of this patron is questionable in two ways. Firstly, this generosity does not apply to every client he had hired, and secondly, the amount of one denarius represented only a mere average of a day's work wage. The way that the patron handles his generosity makes him look historically less credible. In other words, this character is real in the parable world, but unlikely in terms of historical plausibility. A further argument in support of the historical implausibility includes the fact that this patron goes out himself to recruit the workers instead of the brokers. Brokers were mediators between patrons and clients. They were in charge of controlling the second order resources like strategic contact between the clients and the patron or conveying the goods and services from the patron to the clients. 'The best broker', says J.H. Neyrey, 'was a person trusted by both patron and client. He had a foot in both worlds, so that he appreciated the interests of both parties and strove to bridge them. ${ }^{51}$ The presence of a steward-broker is indicated in v. 8 as the one who was in charge of paying the wages. One wonders whether this broker was the best one, as he does not even address a critical question raised by the long day workers. Was his silence an approval or disapproval of his master's decision? Matthew does not seem to be interested in this detail or whether the first-comers went from the steward to the landlord or whether the latter overheard their outcry and intervened to calm the situation. Gundry opines that 'for the sake of the story the evangelist probably means his readers to think - however unrealistically - that the employer is standing by all the time. ${ }^{52}$

Making reference to a redactional choice compels us to look closely to Matthean audience to which this parable was addressed, especially that this story is one of the

48 B. Malina and L. Rohrbaugh, Socio-Science Commentary on the Synoptic Gospels (Minneapolis: Fortress Press, 1992), 124.

49 Ibid., 124

50 Ibid., 124.

51 J.H. Neyrey, 'God, Benefactor and Patron: The Major Cultural Model for Interpreting the Deity in Greco-Roman Antiquity,’ JSNT 27.4 (2005), 476.

52 R.H. Gundry, Matthew. A Commentary on His Handbook for a Mixed Church under Persecution (Grand Rapids: Eerdmans, 1994), 398. 
peculiar sources of the first gospel. There are some literary indices that point the origin of the Gospel of Matthew to Syria: Syria replaces 'Tyre and Sidon' in Matt 4:24 (contra Mark 3:8; Luke 6:17), which suggests that Matthew writes his gospel somewhere in Syria besides Tyre and Sidon. Secondly, in 17:24-27 a stater coin is converted into two double drachmas, which is a transaction needed only in Damascus and Syrian Antioch.

Furthermore, as Gundry argues, 'the Jewish-cum-Gentile character of Matthew fits Luke's description of the Church in Antioch. ${ }^{53}$ In others words, the original Matthean audience would consist of a mixed community made up of Jews (especially Pharisees more loyal to the Torah) and Christian Jews and non-Jews (more loyal to Jesus Christ). As one would expect, any cohabitation often faces internal quarrels. In the present parable, Matthew would be addressing an issue dividing his Christian audience in Antioch, namely the Jewish Christians who undermine the Gentile ones:

Therefore the late-comers in the parable represent Gentiles who have entered the Church only recently from Matthew's standpoint, and the first-comers their detractors among Jewish Christians. The parable appears to play advocacy role for churchly acceptance of believing Gentiles. $^{54}$

With carefully chosen words, Matthew teaches his audience that 'eternal life will come only to workers - i.e. disciples - but as a gift based on divine generosity, not as a wage based on precise calculation. ${ }^{55}$ It is left to the responsibility of each reader to appreciate or question the pertinence of the divine generosity here.

Did Jesus tell this parable or is it just a Matthean creation? It is possible that Jesus would have told such a parable or another similar one which Matthean Sondergut might have edited. The most appropriate historical context for Jesus could be a situation of conflict between him and his disciples on one hand and with religious authorities on the other hand. Such probability seems plausible in the light of an immediate literary context (Matt 19:3-9; 10-12; 27-29), where Pharisees argue with Jesus about the divorce (19:3-9), while his disciples question him further about the marriage and the reward for following him (19:10-12; 27-29). This type of argument between Jesus and his opponents runs throughout the gospel, including contexts in which Pharisees are infuriated when they see Jesus welcoming the sinners and other outcasts. Commenting on Matt 20:11, M.J. Lagrange asserts:

Le plan de Dieu est désormais connu: Dieu est résolu à ouvrir le royaume aux ouvriers de la dernière heure. Jésus accueille les pécheurs et les réconcilie. Mais c'est précisément ce qui exaspère les Pharisiens (God's plan is now known: God is resolved to open the reign to the

53 Ibid., 609; S.C. Mimouni, 'Pour une histoire de la séparation entre les communautés "chrétiennes” et les communautés “pharisiènnes” (ca. 70-135 de notre ère),' Henoch 26.2 (2004), 155.

54 R.H. Gundry, Matthew, 399.

55 Ibid., 399; M.J. Lagrange, L'Evangile selon Saint Matthieu, 385; P. Gaechter, Das Matthaus Evangelium (Innsbruck: Tyrolia, 1963), 633. 
workers of the last hour. Jesus welcomes the sinners and reconciles them. But that is precisely what annoys the Pharisees). ${ }^{56}$

This is an indication that Jesus would have uttered the present parable in a context of Jewish leaders who opposed his ministry of inviting the outcast to share in the heritage of God's Kingdom. As U. Luz puts it: 'Since its contents fit well with Jesus's affirmation of outsiders, poor, and sinners in light of the kingdom of God, hardly anyone has suggested that it does not come from Jesus. ${ }^{57}$

Nevertheless, it should be noted that allegoric interpretations of this parable have flourished not only among Christians but also even among Muslims. The latter view the Jews as the labourers who have worked from morning to noon; the Christians are identified with those who followed from noon to after-noon while those who came in from afternoon to sunset represent the Muslims ${ }^{58} \mathrm{~A}$ Jewish parallel story pictures a labourer who worked for only two hours but received the same wage as those who had toiled for the whole day. The parable was told by Rabbi $\mathrm{Z}^{\mathrm{e}^{\prime}}$ era at the funeral of his teacher Rabbi Bun bar Hijja, who died young at the age of 28 years old (c. $325 \mathrm{CE}$ ), after mastering the Torah more than others in one hundred years (j. Ber 2,8 [.5c]). ${ }^{59}$ The trend of Jewish meritocracy is obvious here, but other texts discourage the idea of working for a reward and consider God's reward as a free gift (Antigonus of Soko in $m$. Abot $1.3,13 ; 4.5) .{ }^{60}$

Each vineyard labourer has been hired either on contract or non-contractual basis. Each one freely accepted to work within limited space and time frames. Each one evolved from idleness to action. Each one received the same treatment thanks to the free will of the landlord. There is no point in being jealous. What matters is to work courageously without envying others and to contribute in improving on the situations of the less fortunate and to participate in the furtherance of God's will on earth as it is heaven (Matt 6:10).

\section{CONCLUSION}

Can the struggle for the just wage and its implementation contribute decisively in alleviating poverty? I have used arguably one of the most appropriate NT passages (Matt 20:1-16) and a more inclusive method (intercultural exegesis) to tackle this question from a biblical perspective. This intercultural study has shown that poverty counts its victims among labour forces who are underpaid (or even underemployed), because they cannot meet their basic living cost (cf. the low paid labourers in the DRC,

56 M.J. Lagrange, L'Evangile selon Saint Matthieu, 389.

57 U. Luz, Matthew 8-20, 526.

58 J. Gnilka, Das Matthausevangelium. (2 vols.; Freiburg-Basel-Wien: Herder, 1988), 181.

59 G. Theissen and A. Merz, The Historical Jesus. A Comprehensive Guide (Göttingen: Vandenhoeck \& Ruprecht, 1996), 346.

60 U. Luz, Matthew 1-7, 535; W. Horbury, W.D. Davies and J. Sturdy, eds., The Cambridge History of Judaism. Volume 3: The Early Roman Period (Cambridge: Cambridge University Press, 1999), 432. 
the appeal from the Catholic Church leaders for a just wage, and the joblessness of the labourers hired in Matt 20:1-20). Nevertheless, underpayment or unemployment should not be regarded as the primary cause of poverty. Similarly, even the relative generosity of an employer would not suffice to strike off poverty. Poverty is a result of a broader sceptre of injustice. The historical context of Matt 20:1-16 indicates that the job seekers of the parable are ultimately people who were unjustly driven out of their land. The Congolese people are becoming poorer as they are losing not only their lands but also the sense of justice and discipline. One neighbouring country, Rwanda, is proving this point, at least in terms of some justice and discipline. The Catholic Church tradition preaches justice in all dimensions of social life, including just wages. Those who put this teaching into practice live happier without necessarily having just wages. Giving just wages or increasing salaries would not eradicate poverty where justice and discipline are lacking. Finally, the parable of Matt 20:1-16 does not prescribe just wages as the remedy for alleviating poverty; it rather provides grounds for promoting justice which goes beyond just wages.

\section{BIBLIOGRAPHY}

Akper, G.I. 'From Multiculturality to Interculturality? Locating the Ongoing African Agency Discourse in the Debate.' Scriptura 91.1 (2006), 1-11.

Amjad-Ali, C. 'Whose Justice: The Parable of the Laborers in the Vineyard.' Al-Mushir 30 (1988), 136-140.

August, K.T. 'The Nature of Interculturality in Development: A Theological Perspective of Relationality.' Scriptura 91.1 (2006), 12-18.

Bahujimihigo, K. Témoins de Dieu dans un pays meurtri. Kigali: Pallotti Press, 1998.

Barré, M.L. 'The Workers in the Vineyard.’ Bible Today 24 (1986), 173-180.

Bauckham, R. The Bible in Politics. How to Read the Bible Politically. London: SPCK, 1989.

Blount, B.K. Cultural Interpretation. Reorienting New Testament Criticism. Minneapolis: Fortress Press, 1995. Repr., Minneapolis: Hoedemaker, 1997.

Brown, R.E. and Molonely, F.J. An Introduction to the Gospel of John. New York: Doubleday, 2003.

Curtis, W. A. 'The Parable of the Laborers (Matt XX. 1-16).' The Expository Times 38 (1926-1927), 6-10

Cyril of Alexandria. 'Fragmenta in Matthaeum.' Frag. 226,229 in Matthäus-Kommentare aus der griechischen Kirche. Edited by J. Reuss. Berlin: Akademie-Verlag, 1957.

Dauphinais, M and Levering, M. Reading John with St. Thomas Aquinas. Theological Exegesis and Speculative Theology. Washington: Catholic University of America, 2005.

De Guibert, F.X. Evangile de Matthieu. 2d ed. Paris: de Guibert, 1996.

De Lichtbuer, P.C. Parabels van het Koninkrijk. Jezus openbaart het gelaat van de Vader. 2 vols. Heverlee: Pierre Cardon de Lichtbuer, 2001.

Derret, J.D.M. 'Workers in the Vineyard: A Parable of Jesus.' Journal of Jewish Studies 25 (1974), 64-91. 
Dietzfelbinger, C. 'Das Gleichnis von den Arbeitern im Weinberg als Jesuswort.' Evangelische Theologie 43 (1983), 126-137.

Doyle, B.R. 'The Place of the Parable of the Labourers in the Vineyard in Matthew 20:1-16.' Australian Biblical Review 42 (1994), 39-58.

Draisma, S., ed. Intertextuality in Biblical Writings. Festschrift B. Van Iersel. Kampen: Kok Press, 1989.

Drewermann, E. Das Matthausevangelium. Bilder der Erfuellung. Düsseldorf: Walter, 1994.

Dupont, J. 'Les ouvriers de la vigne (Matthieu XX,1-16).' Nouvelle Revue Théologique 79 (1957), 785-97.

—_. 'Les Ouvriers de la vigne.' Assemblée du Seigneur 22 (1965), 28-51.

. 'Les ouvriers de la onzième heure. Mt 20,1-16.' Assemblée du Seigneur 56 (1974), 16-27.

Feuillet, A. 'Les ouvriers de la vigne et la théologie de l'alliance.' Recherches de Science Religieuse 34 (1974), 303-327.

—. 'Les ouvriers envoyés à la vigne (Mt XX, 1-16).' Revue Thomiste 79 (1979), 5-24.

Gaechter, P. Das Matthaus Evangelium. Innsbruck: Tyrolia, 1963.

Geertz, C. The Interpretation of Cultures. New York: Basic Books, 1993.

Genette, G. Palimpsestes. La litérature au second degré. Paris: Seuil, 1982

Glasswell, M.E. 'Parable of the Labourers in the Vineyard (Matthew 20,1-16).' Communio Viatorum 19 (1976), 61-64.

Glover, F.C. 'Workers for the Vineyard.' The Expository Times 86 (1975), 310-11.

Gnilka, J. Das Matthausevangelium. 2 vols. Freiburg-Basel-Wien: Herder, 1988.

González, J.L. 'Reading from My Bicultural Place: Acts 6:1-7.’ Pages 139-147 in Reading from This Place. Volume 1: Social Location and Biblical Interpretation in the United States. Edited by F.F. Segovia \& M.A.Tolbert. Minneapolis: Fortress Press, 1995.

Greogry the Great. 'XL Homiliarum in Evangelica.' Pages 1156-1157 in Patrologia Latina 76. Edited by J.P. Migne. Paris: Brepols, 1857.

Gundry, R.H. Matthew. A Commentary on His Handbook for a Mixed Church under Persecution. 2d ed. Grand Rapids: Eerdmans, 1994.

Haubeck, W. 'Zum Vertändnis der Parabel von den Arbeitern im Weinberg (Mt 20,1-15).' Pages 95107 in Wort in Zeit. Neutestamentliche Studien. Festgabe für Karl Heinrich Rengstorf zum 75. Geburtstag. Edited by W. Haubeck and M. Bachmann. Leiden: Brill, 1980.

Horbury, W. Davies, W.D and Sturdy, J., eds. The Cambridge History of Judaism. Volume 3: The Early Roman Period. Cambridge: Cambridge University Press, 1999.

Izia-Mpey, C. 'Education congolaise et exigences fondamentales du développement.' Revue Africaine des Sciences de la Mission 20/21 (2005), 197-244.

Jeremias, J. The Parables of Jesus. New York: Charles Scriber’s Sons, 1972.

John Chrysostom. 'Homiliae in Matthaeum 64.3.' Pages 647-654 in Patrologia Graeca 58. Edited by J.P. Migne. Paris: Brepols, 1862.

John Paul II. 'Laborem Exercens.’ Acta Apostolicae Sedis 73 (1981), 629-632.

John Paul II. 'Centesimus Annus.’ Acta Apostolicae Sedis 83 (1991), 801-802.

Jean-Paul II. Exhortation apostolique post-synodale Ecclesia in Africa. Kinshasa: Mediapaul, 1995. 
John XXIII . 'Pacem in Terris.’ Acta Apostolicae Sedis 55 (1963), 262-263.

Jonker, L. 'From Multiculturality to Interculturality: Can Intercultural Biblical Hermeneutics be of any Assistance?’ Scriptura 91.1 (2006), 19-30.

Jülicher, A. Die Gleichnisreden Jesu. Tübingen: Mohr, 1910. Repr., 1919.

Kalibwana, J. Le Catholicisme et la societé rwandaise 1900-1962. Paris : Présence Africaine, 1991.

Kiessel, M.E. 'Intertextualité et hypertextualité en Jn 11,1-12,11.' Ephemerides Theologicae Lovanienses 81.1 (2005), 25-56.

Kloppenborg, J.S. The Tenants in the Vineyard: Ideology, Economics, and Agrarian Conflict in Jewish Palestine. Tübingen: J.C.B. Mohr, 2006.

_. 'The Growth and Impact of Agricultural Tenancy in Jewish Palestine (III bce - I ce)', Journal of the Economic and Social History of the Orient 51.1 (2008), 31-66.

Lagrange, M.J. L'Evangile selon Saint Matthieu. 3d ed. Paris: Gabalda, 1941.

Lebacqz, K. 'Justice, Economics, and the Uncomfortable Kingdom: Reflections on Matthew 20:1-16.' Pages 27-53 in The Annual of the Society of Christian Ethics. Edited by L.L. Rasmussen. Dallas: Society of Christian Ethics, 1983.

Leo XIII. 'Rerum Novarum.’ Acta Leonis 11 (1892), 133-135.

Linden, I. Christianisme et pouvoirs au Rwanda (1900-1990). Paris: Karthala, 1999.

Linnemann, E. Jesus of the Parables. New York: Harper \& Row, 1966.

Loba-Mkole, J.C. 'The New Testament and Intercultural Exegesis in Africa.' Journal for the Study of the New Testament 30.1 (2007), 7-28.

Lowe, M. 'A Hebraic Approach to the Parable of the Laborers in the Vineyard.' Immanuel 24/25 (1990), 109-117.

Luz, U. Matthew 8-20. Minneapolis: Fortress Press, 2001.

Luz, U. Studies in Matthew. Grand Rapids: Eerdmans, 2005.

Luz, U. Matthew 1-7. Minneapolis: Fortress Press, 2007.

Malina, B. and Rohrbaugh, L. Socio-Science Commentary on the Synoptic Gospels. Minneapolis: Fortress Press, 1992.

Marguerat, D. \& Curtis, A., eds. Intertextualités: La Bible en échos. Genève: Labor et Fides, 2000.

Menahem, R. 'Epitropos/Paqid in the Parable of the Laborers in the Vineyard.' Immanuel 24/25 (1990), 118-131.

Michaelis, W. Die Gleichnisse Jesu. Hamburg : Furche-Verlag, 1956.

Mimouni, S.C. 'Pour une histoire de la séparation entre les communautés “chrétiennes" et les communautés “pharisiènnes” (ca. 70-135 de notre ère).’ Henoch 26.2 (2004), 145-171.

Mitton, C. L. 'Expounding the Parables: The Workers in the Vineyard (Matthew 20:1-16).' Expository Times 77 (1965-1966), 307-311.

Muyebe, S. and Muyebe, A. The African Bishops on Human Rights. A Resource Book. Nairobi: Paulines Publications Africa, 2001. Repr., 2002.

Ndaywel è Nziem, I. Histoire générale du Congo. De l'héritage ancien a la République Démocratique. Paris-Bruxelles: Duculot, 1998.

Neyrey, J.H. 'God, Benefactor and Patron: The Major Cultural Model for Interpreting the Deity in Greco-Roman Antiquity.’ Journal for the Study of the New Testament 27.4 (2005), 465-463. 
Pak, C.H. 'Die Arbeiter im Weinberg (Mt 20,1-16).’ Bibel und Kirche 52 (1997), 136-137.

Pius XI. ‘Quadragessimo Anno.’ Acta Apostolicae Sedis 23 (1931), 186.

Pius XII 1939. 'Sertum Laetitiae.’ Acta Apostolicae Sedis 31 (1939), 643.

Pontifical Council for Justice and Peace. Compendium of the Social Doctrine of the Church. Vatican: Libreria Editrice Vaticana, 2004.

Räisänen, H. Challenge to Biblical Interpretation, Essays 1991-2000. Leiden: Bril, 2001.

Rodriguez, J.D. 'The Parable of the Affirmative Action Employer.' Apuntes 15.5 (1988), 418-424.

Ru, G. 'Conception of Reward in the Teaching of Jesus.' Novum Testamentum 8 (1966), 202-222.

Rutayisire, P. La Christianisation du Rwanda (1900-1945). Méthode missionnaire et politique selon Mgr Léon Classe. Fribourg: Editions Universitaires, 1987.

Santedi, L. 'Les défis de l'évangélisation dans l'Afrique contemporaine.' Pages 187-199 in Inculturation de la vie consacrée en Afrique à l'aube du troisième millénaire. Edited by J. Kalonga. Kinshasa: Carmel Afrique, 1998.

Schenke, L. 'Die Interpretation der Parabel von den 'Arbeitern im Weinberg' (Mt 20,1-15) durch Matthäus.’ Pages 245-268 in Studien zum Matthäusevangelium: Festschrift für Wilhelm Pesch. Edited by L. Shenke. Stuttgart: Katholisches Bibelwerk, 1988.

Schneider, F. 'Von der Gerechtigkeit Gottes: Beobachtungen zum Gleichnis von den Arbeitern im Weinberg (Mt 20,1-16).’ Kairos 23 (1981), 88-95.

Scott, B.B. Hear Then the Parable. A Commentary on the Parables of Jesus. Minneapolis: Fortress Press, 1989.

Second Vatican Ecumenical Council. 'Gaudium et Spes.' Acta Apostolicae Sedis 58 (1966), 10891090.

Segovia, F.F. 'Towards a Hermeneutics of the Diaspora: A Hermeneutic of Otherness and Engagement.' Pages 57-73 in Reading from This Place. Volume 1: Social Location and Biblical Interpretation in the United States. Edited by F.F. Segovia and M.A. Tolbert. Minneapolis: Fortress Press, 1995.

—. 'Towards Intercultural Criticism: A Reading Strategy from the Diaspora.' Pages 303-330 in Reading from This Place. Volume 2: Social Location and Biblical Interpretation in Global Perspective. Edited by F.F. Segovia and M.A. Tolbert. Minneapolis: Fortress Press, 1995.

Simonetti, M. Ancient Christian Commentary on Scripture. New Testament. Matthew 14-28. Downers Grove: InterVarsity Press, 2001.

Spies, O. 'Die Arbeiter im Weinberg (Mt. 20:1-15) in islamisher Überlieferung.' Zeitschrift für die neuetestamentliche Wissenschaft 66 (1975), 279-83.

Tevel, J.M. 'The Labourers in the Vineyard: The Exegesis of Matthew 20,1-7 in the Early Church.' Vigiliae Christianae 46 (1992), 356-80.

Theissen, G. and Merz, A. The Historical Jesus. A Comprehensive Guide. Göttingen: Vandenhoeck \& Ruprecht, 1996.

Thiselton, A.C. Thiselton on Hermeneutics. Collected Works and New Essays of Anthony C. Thiselton. Aldershot and Burlington: Ashgate, 2006.

Ung'eyowun, B. E. 'Les défis de l'évangélisation et de l'engagement missionnaire renouvelé en Afrique.' Revue Africaine des Sciences de la Mission 20/21 (2005), 185-196. 
Vearncombe, E.K. 'Redistribution and Reciprocity: A Socio-Economic Interpretation of the Parable of the Labourers in the Vineyard (Matthew 20.1-15).' Journal for the Study of the Historical Jesus 8 (2010), 199-236.

Via, D. Jr. The Parables. Their Literary and Existential Dimension. Philadelphia: Fortress Press, 1967.

West, G. Biblical Hermeneutics of Liberation. Modes of Readings the Bible in the South African Context. Pietermaritzburg: Cluster; New York: Orbis Books, 1995.

Williams, W. T. 'The Parable of the Labourers in the Vineyard (Matthew xx. 1-16).' The Expository Times 50 (1938-1939), 526.

Wimbush, V.L. 'Reading Texts as Reading Ourselves: A Chapter in the History of African-American Biblical Interpretation.' Pages 95-108 in Reading from This Place. Volume 1: Social Location and Biblical Interpretation in the United States. Edited by F.F. Segovia and M.A. Tolbert. Minneapolis: Fortress Press, 1995.

Yarbro-Collins, A. ‘Narrative, History and Gospel.’ Semeia 43 (1988), 145-153. 